Toshio Sugr : Breeding of industrial crops. Jap. J. Breeding. Vol. 11, No. 2. 1961

\title{
特用作物 の育種
}

\author{
杉頴 夫 \\ (輙林省振與局研究部)
}

由来，特用作物には，同じ用途への工業成品の急速な 進出，これに伴う国内のみならず海外の需用の動向なぞ 稲麦などの主要食糧農作物とは著しく翼つた諸状勢の影 響を直接にうけるものが多い。戦後，特用作物関係の育
種事業の改廃の多かつたのむ，このような背景があつた からにほかならない。

これを一括すれば次の表の如くである。

最近 10 年間汇括ける特用作物育種試験地の改廃（国費に上る分）

\begin{tabular}{|c|c|c|c|c|c|c|}
\hline \multirow{2}{*}{\multicolumn{2}{|c|}{ 作物 名 }} & \multicolumn{2}{|c|}{1950 年. } & \multicolumn{2}{|c|}{1960 年 } & \multirow[b]{2}{*}{ 摘 } \\
\hline & & 国立濃 試 & $\begin{array}{l}\text { 指 定 試 駰 } \\
\text { (都道拊県) }\end{array}$ & 国立農試 & \begin{tabular}{|c|} 
指 定 試 験 \\
(都道府県)
\end{tabular} & \\
\hline 要 & 麻 & 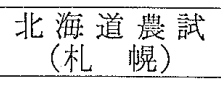 & 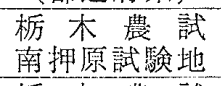 & $\begin{array}{c}\text { 北海: 道農試 } \\
(\text { 札 帺) }\end{array}$ & 1958年廃止 & \\
\hline 大 & 麻 & & 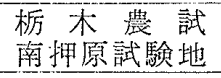 & & 1958年廃止 ${ }^{1)}$ & \\
\hline 苧 & 麻 & 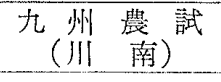 & & 1960年廃止 & & 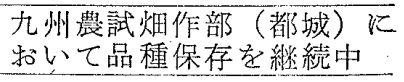 \\
\hline 棉 & & & 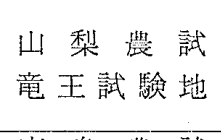 & & 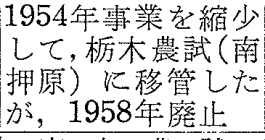 & $\begin{array}{l}\text { 愛知農圾豊橋分場飞数いて } \\
\text { 品種保存を継続中 }\end{array}$ \\
\hline 䦧 & 草 & & 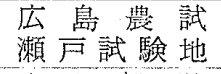 & & 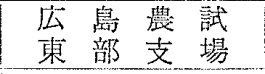 & \\
\hline 楮・三 & 樫 & & $\begin{array}{l}\text { 高知 濃試 } \\
\text { 別府分場 }\end{array}$ & & 1958年廃止 & \\
\hline 薄 & 倚 & 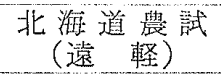 & $\begin{array}{l}\text { 岡山豊陚 } \\
\text { 倉敷 贫 }\end{array}$ & 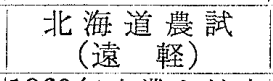 & $\begin{array}{l}\text { 阔山震試 } \\
\text { 倉敷分場 }\end{array}$ & \\
\hline 除 虫 & 菊 & $\begin{array}{c}\text { 北海道㤟試 } \\
\text { (遠 軽) }\end{array}$ & $\begin{array}{l}\text { 広島 農 誡 } \\
\text { 重井試験地 }\end{array}$ & 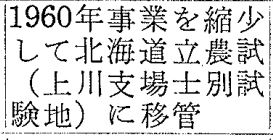 & 1958年廃此 ${ }^{1)}$ & \\
\hline 薬用人 & & & 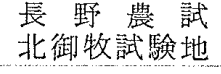 & & 1958年廃止 & \\
\hline 小 ッ & プ & & 長野農試 & & 1955年廃止 ${ }^{1)}$ & \\
\hline 蒟 & 蒻 & & 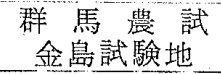 & & $\begin{array}{l}\text { 群 馬 農 試 } \\
\text { 金島語試験地 }\end{array}$ & \\
\hline 菜 & 種 & $\begin{array}{c}\text { 東海近畿)農試 } \\
\text { (津) }\end{array}$ & $\begin{array}{l}\text { 福島農 試 } \\
\text { 福試 }\end{array}$ & 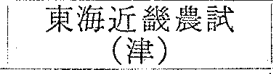 & $\begin{array}{l}\text { 福易農 試 } \\
\text { 福誠試 }\end{array}$ & \\
\hline 甜 & 菜 & $\begin{array}{l}\text { 北海道農試 } \\
\text { (札 愰) }\end{array}$ & & $\begin{array}{c}\text { 北海 道農試 } \\
\text { (札 棍) }\end{array}$ & & $\begin{array}{l}\text { 1960年特殊法人てん菜振興 } \\
\text { 会のん菜研究所（札熀及 } \\
\text { び熊本) が設立された }\end{array}$ \\
\hline
\end{tabular}

註 1) いずれも, 廃止後, 事業規模を縮少し, 当該県農試の単独事業として, 継続奏施中

\section{I. 菜種}

組織的育種事業は 1930 年に開始されたが，1947 年及 び 1950 年に育種組織の改変があつて 1960 年現在は福 島, 福風の 2 県農試に和㺭る指定試験及び東海近畿農試 (津)の 3 ケ所化いて育種事業がすすめられている。
事業の初期から昭和の中期頃までは，主として当時混 系であつた優良な在来品種（尃ら Napus に属する品種， 例えば早生朝鮮, 四日市黒種なぞ）を対象として, 系統 選抜が行われた。しかし裏作物としての菜種の作付体系 上の性格から，育種目標として耐湿性・早熟性（水田裏 
作対象）或いは酎雪性・耐寒性（特に東日本烟作対象） などの特性が重視されるようになると，これらの特性を 具えた Campestris が種間交配用母本として極めて重要 な役割を果すようになつた。

種間交配 $(N \times C)$ 飞上る実用品種は 1939 年以育成さ 秃た農林 7 号をるつて最初とするが，試み㵊近 10 年 間飞上記 3 育種試験地比いて育成された 14 品種につ いてみるとそのうち6品種が $\mathrm{N} \times \mathrm{C}$ (うち1品種は $\mathrm{N} \times$ $(\mathrm{N} \times \mathrm{C}))$ となつている。

かかる育種方法が，早くから实用化したのは Brassica 属の細胞遗伝学的研究, 就中禹氏等のグノム分析の研究 记負らところ大で，わが国の育種史上特記すべきことで 必る。

1960 年現在, 農林番号登録品種は 32 をが炎, それ らは菜種総栽培面積の約 $90 \%$ 飞達し, 育成品種の普及 率は主要作物中首位を占好てる。

3ケ所の育種試験地の分担地域は大をかにいらと, 福 島県農試が東北, 関東東山及び北陸, 東海近畿農試が東 海近畿, 山陰地方, 福岡県擃試が九州, 山陽地方とない ていて，炎れぞれの育成品種も大体当該地方に普及して いる。

これに関連し早急に考えね就ならぬことは菜種の茷培 地域の南及び北への重点移動（尃ら畑作）飞対応する育 種体制の問題及び氷田裹作に扝惪播栽培に対応する 品種の問題である。

すなわち第 1 点については, 最近の北海道及び東北北 部地带に挌将る著しい裁培增加と, 主として麦作転換の

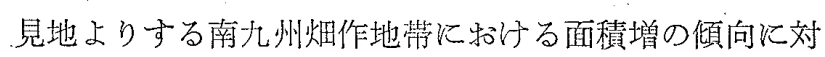
処して，それぞれの地满に新たな育種試験地を必要々す るで岕らう。このうち北海道農試では 1957 年より, 在 来品種ハンブルグよりの系統分離を行つて拉り, 交配育 種も1959 年より開始された。

第 2 点は主として福岡農試及び東海近畿農試における こんごの主要育種目標で岁るが，水稻の早期栽培立びに 早植栽培とも関連し，一段と熟期の繰上げが要望される がこの場合熟期は早いが抽苔は比較的呿そい特性をるつ 品種（例壳ばミユキナタネの如き）が湅霜害の回避の見 地からのぞましい。更に菜種最大の病害で岁る菌核病耐 病性は西日本の暖地沈抢いては最も要請の急な特性であ る。

これらに関連し，ここ数年来単為生殖绫導操作による 方法, 底交配法, 更に最近に和いてはコルヒチンやて線 利用も試みられたが，いまだ実用的品種の育成をみるに 至っていない。

なお 1961 年飞鹿児島農試（鹿屋支場）に，南九州を 対象として新たに指定試験が設置され，育種事業が開始
されることになつた。

\section{II. 甜 菜}

北海道農試汇打ける甜菜育種は古く, 人工交配も 1924 年以降行示れ，本育 190 号 (1935) 及び同 192 号 (1935) が育成されて全道譜及した。また集団選拔法により， 本育 398 号 (1942) が育成された。このように従来は集 団選抜法, 交配法, 系統分離法が平行して実施されてさ たが，いずれる高性能品種育成に対しては必ずしも充分

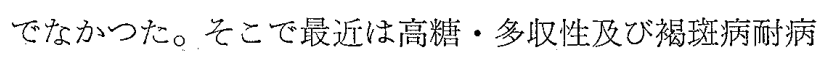
性を重要育種目標とし, その手段としては輸入品種の利 用, 雑種強勢の利用, 倍数体の利用などがとり上げられ るようになつた。

最近 10 ケ年に赫计る品種の消長を及ると 1952 年以 降 leading variety は導入品種炕きか方和た。導入 品種は米国より輸入され，いずれも褞斑病治く，特汇 導入 2 号 (GW 359) はすぐれていたので優良品種として 集団選抜法に上る原及種の生産が開始され，1956年以降 本品種の原々種は $90 \%$ （本育 129 号が 10\%）を占める に至つた。

しかし本品種の育成材料飞は野生種 Beta maritima が用いてめるため, 分岐根多く, 晚生且つ歩留りが比較 的低いという点があり, 1957年以降, 早熟性・高糖の

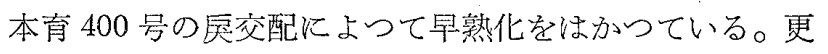

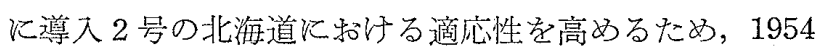
年より循環選抜法及び母系選抜法を試み，1960年可製糖 量飞招いて導入 2 号に立さる合成 2 号が育成された。

一方杂倠種強勢利用のため, 1942年以来自殖系統の育成 が行われていたが，1951年より3ケ年に亘つてこれら系 統の組合せ能力を検定し，優良系統の 混合により $\mathrm{Sy}-$ A, Sy-B の合成品種が育成され, 特飞 Sy-B 跣耐病性 強く, 可製糖量飞执いて子本育 192 号にまさるので, 1960年合成1号として, 前記合成 2 号とともに新品種に 登録された。

倍数体利用汇ついては，1940年以来木原生研, 北大, 北海道農試の協力によつて研究がすすめられてきた。最 近わが国海俞入された 3 倍体の品種に注可成りよいもの が認められる。

一代雑種並びに 3 倍体の種子生産飞は, 雄性不稔形質 の利用が大きな課題になつているが，1949年以来この研 究汇着手し, 現在導入 2 号を母材とした雄性不稔系統の 育成をすすぬている。

更浽褐病々原性と耐病性の問題, Rhizoctonia 耐病 性品種の育成, 野生種の利用, 単胚種の育成なぞいずれ も重要なことであるが，これらについては，小規模な研 竿が行われているにすぎない。

こんごの問題としては, 各地帯別の適品種の育成を考 


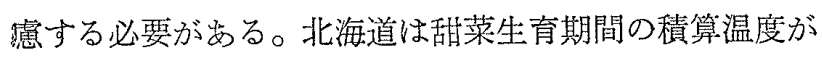
$2400^{\circ} \mathrm{C}$ 以下, $2400^{\circ} \mathrm{C} \sim 2700^{\circ} \mathrm{C}, 2700^{\circ} \mathrm{C}$ 以上の 3 地带に 大別しらる。 $2400^{\circ} \mathrm{C}$ 以下の地带には現在本育 192 号が载 培されているが，一段と早熟性で多る程度耐病性の女る 品種, $2400^{\circ} \mathrm{C} \sim 2700^{\circ} \mathrm{C}$ の地带では導入 2 号の酎病性で 更に多収・高糖の品種, $2700^{\circ} \mathrm{C}$ 以上の地带では䶂斑病耐 病性で高歩留りの品種がそれぞれ要求されている。

また根瘤線虫，virusなどの抵抗性附与も重要であろ 5 。

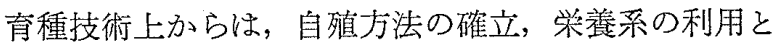
育種年限の短縮などな和残された問題がある。

更に府県に括ける甜菜栽培の進展は，特に北海道己は 全く異る栽培体系をとる暖地の場合, 生態型を異にする 品種の育成を急務として拈り，また東北地方から関東に 至るいわゆる中間地帯に和いては，さし当り葉腐病耐病 性品種の欠除が痛感される。

\section{III. 藺草}

1947年に広島農試に指定試験が設置されて以来，各地 から栽培年数の長い在来種を蒐集しその特性を調査して 部画的育種が開始された。当初は専ら栄養系分離による 育成, 1951年からは人工交配法がとられるようになつた。 栄養系分離によつて，広島 6 号から瀬户 1 号，高須在 来から瀬戸 2 号が育成された。瀬戸 1 号は，中細の良質 品種 (手織用) として，1956 年に広島県の将励品種とな り，次いで 1957 年瀬戸 2 号が伸長の良い多収品種（動 力織用）として，サザナミと命名され藺草として最初の 農林番号品種に登録された。

また 1955 年に千丁在来から瀬戸 4 号が㕕成され，近 く岡山県に扣いて奨励品種に編入される筈である。

一方 1949 1951 年に実生養成法が泳ぼ確立されるに 至つて，交雑育種について漸くその見通しが得られるよ うになり，自花授粉，自然授粉種子及び人工交配種子よ りの実生養成炕るる育種に着手したが，現在のところ成 果を岕げるに至つていない。

1952 年にコルヒテン滴下（苗の芽に対し）処理を行つ て, 倍数体と思われるものを育成し，また1956年てホソイ (Juncus setchnensis BUCH. var. effusoides BUCHEN) $\times$ 広島 6 号 (J.effusus L. var. decipiens BUCHEN) の 種間雑種を得たが，ともに着花が多いことなど実用価值 がなく，優良系統は得られなかつた。

以上の如く交雑育種に拈いては，見るべき成果を得て いないので，こんごは交配花数及び実生湌成の成苗数を 多くするとともに， $\mathrm{F}_{2}$ 選抜を行い，苗床選抜法を確立し 育成能率をたかめる必要がある。

また耐倒状性, 耐病性品種の育成には, 着花の少い野
生種と栽培種との種間雑種の利用をはかるとともに, 既 存品種のコルヒチン処理によつて, 伸長のよい多収品種 の選抜や，更には 3 倍体の育成多考兄らる。X 線や $\mathrm{Co}^{60}$ などによる笑然変異利用の可能性についてす研究を すすめるべきであろう。

\section{IV，垔麻}

北海道に打汗る覀䏫の育種事業は甜菜之同様1920年頃 から計画的に行われるようになり、ペルー1号(1924)， サギノー1号(1937)などが純系啣汰法によつて育成され たが，交雑育種法がとられるようになると立枯病に強い 南捷 (1939) や南翼 (1944), 更に銹病に強くて多収の雲 竜（1949）などが育成されて，育種事業は軌道にのつた。

ここ10 年間に和いては，その前半は耐病・多収を, 後半は耐倒伏性・高繊維步留を主目標として育成が行わ れた。このような育種目標の変化は，最近の化繊，合繊 の急速な発達や国際市場に叔ける競争など, 社会的, 経 済的な影響を強くうけたことと無関係ではない。

立怙病及び銹病耐病性で多收な品種として管成された ものに，要浐やぎ (1955) 及び本系 55 号が女る。従来の 耐病性品種は，立枯病か銹病のいずれか一方㑔病性で 岁るか，或いは雲竜の如く酎病性は強いが，その耐病親 とした種子用品種の低い縬維歩留りを伴つたるのであつ た。女特やきと本系 55 号はかかる欠陷を少なくした品 種で岁る。

最近に特ける亜麻栽培面積の減少とともに病害の発生 も減り，乙れに対する耐病性品種よりも，多肥密植によ る多収栽培や収穫学力の軽減, 収穫の機械化を可能なら しめる酎倒伏性品種の育成が必要となり，ま艾界から は採繊率のよい高歩留品種が要求されるに至つた。

1957 年耐倒伏性品種ウィーラ(ベルギー) の導入によ り倒伏は著しく減少し, 多肥密稙栽培が可能となつたこ とは注目される。

な招杤不農試南押原試験地 (現鹿沼分場) に招いては, 1950年頃より関東以西の水田裹作を対像として, 早生・ 耐倒代性品種の育成を小規模ながら始めたが，若干の系 統を選抜しただけで，この事業は1958 年に打切られ た。

北海道に括けるこんごの問題としては，まず，現在の 耐倒伏性品種の程度では，多湿の条件下での倒伏回避は 困難であり，収穫機の導入を考飶すると，更汇耐倒伏性 の強化が必要である。また酎倒伏性を附与する場合，織 維歩留が低下することが多いが，むしろこれを向上せし めることが採緎コストを低下させる条件となるであらう。 次に最近 Rhzoctonia に上る立枯病及び線虫の被害が 多発しているので, これらに対する耐病, 耐線虫性品種 
も必要である。

また現在の多収品種はいずれも晚熟であつて，収穫期 に降雨に遭遇することが多いため，更酒麻作の大半が 赤クロバー，チモシーなどと混作されて和り，これらあ と作の生育をよくするため，ともに熟期の早期化がのぞ ましい。

\section{V. 薄 荷}

1936 年に北海道立農試 (北見支場) 及び岡山農試（倉 敷試験地）に指定試験が設置されたが，これより先，北 見支場では系統分離によつて赤円（1924）及び北見白毛 (1932)が充成されていた。

しかしこれらの品種はいずれも銹病に弱かつたので， 1947年以降, 支那溥荷 (Menta arvensis var. glabrata $2 n=96)$ との交杂隹種が開始され，之の結果現在北海道 の奖励品種として広く普及している万葉（1953）及び涼 風（1954）孞育成された。

特に万葉は吸肥力が強く，著しい多取のため，従来の 栽培法を一変するに至つた。本品種の銹病耐病性もなお 充分でないが，日本薄荷品種間交配では，耐病性育種に は限度が女ると思われるので，耐病性の極めて強いスぺ アミント系の野生種 (M. spicata， $2 n=48$ や. spicata var. crispa， $2 n=48 ）$ と日本薄荷との種間交雑による 育成が期待される。

一方暖地を対象とした岡山農試に和いても, 在来種を 多数䈭集し，特性調查を行つた結果，特に細分の高い一 系統（紅茎）索優良とみとめ，1953 年に三美と命名し奖 励品種とした。

1953年以降は品種間交配と自殖とを併用し，1958年に は青茎種の自殖系統から選拔された耐旱性強く，香りの よいはくびが䏍成されて，三美と括さかわりつつおる。

末た 1955 年以来, $2 n=108$ の系統と日本薄荷とを交 配して染色体増加による育種が計画され，現在 $2 n=120$ の優良系統が得られている。

銹病抵抗性の附与と立んで，特飞業界からは芳香性品 種の育成の要望が強い。この場合にも前記の M. spicata や西洋薄荷 (M. piperita) との種間交配に期待がかけら れる。種間交配により暖地に適応寸る生育型の品種を育 成することは理論的に可能であることが明がされてい るが，ただこの種間交配の $\mathrm{F}_{1}$ は汪とんど不稳となるた め染色体倍加による稔性增加の研究が必要である。

\section{VI. 除虫菊}

1935年に北海道立農試 (和寒試験地), 広島農試 (重井 試験地) 及び和歌山農試（主として貯蔵法の試験を担当） にそれぞれ寒地及び暖地を対象とする指定試騟が設置さ れ，育種事業が開始された。
北海道で洼 1943 年に在来種からの選抜によつて北海 1 号 (中生種) 及び北海 2 号 (早生種) が育成さ机た。と もに 3 倍体で多収，ピレトリン含量も多く，耐病性（立 枯,菱縮病)・耐寒性も大で女り，特に北海 1 号はすぐれ て拉り,現在に至るまで北海道に利ける leading variety となつている。

3 倍体でめるため，種子繁殖が不可能で，増殖は専ら 株分けによらねばならず，従つて増殖率は低い。

除虫䍜の育種法は種子繁殖による系統育成と無性繁殖 によるそれとに大別されるが，北海道では後者をとり， 優良個体の選抜力法としては，1）一般農家で栽培して いる在来種からの優株の蒐集選抜，2) 交配(特に 2 倍体 $\times 4$ 倍体）の $\mathrm{F}_{1}$ からの 3 倍体の選抜，3）種子繁殖系統 （特にアフリカのケニア産種子）からの個体選抜，4）突 然変異誘起（2倍体系統種子のX線処理）による個体選 抜があり，現在約 50 柔統を選拔している。

な䄈 4 倍体は着花数少なく，ピレトリン含量も少なく 実用的価值の女る有のは見出されていない。

広島では，夏季高温のため株が夏枯れを特こすので種 子繁殖用品種（2 倍体）の育成飞努力をつづけたが，充 分の成果を得ることがでさなかつた。そこで 1951 年以 降は次の方法によつて育成をすすめた。

即ち交配和合性の組合せについて，まず採種を行い， これらの種子穵組合せ每に播種して，生産力その他の特 性につき次代鑑定を行う。その結果優良であれば，当該 組合母本 (親株) を無性繁殖により堌殖（県内の高冷地 に执いて）し，組合せ每に隔離栽培して年々採種する。 この種子を一般栽培用とする。一般の採花普通栽培農家 は年々隔離採種围から種子の供給をうけ，自家採種は行 わない。この力法により，現在一，二の有望系統が選出 されつつ要る。

以上のほか育種事業を実施している特用作物はな呿数 種類女るが，このうらにはここ10 ケ年の間に事業を打 切つた作物る安る。

それら作物决いて，その経過を述べることは省略す るが，育成された品種文は優良系統を一覧すれば次の如 くである。

\begin{tabular}{|c|c|c|c|}
\hline 作物名 & 品種・系統名 & $\begin{array}{l}\text { 垐成 } \\
\text { 年次 }\end{array}$ & 筲成試験地 \\
\hline 棉 & ムサシワタ & 1953 & 山梨濃試 竜王試験地 \\
\hline 大 麻 & 南押原 1 昂 & 1950 & 栃木農試南押原試験地 \\
\hline \multirow[t]{2}{*}{ 苧 䏫 } & しらぎね & 1958 & 九州濃試 川南試験地 \\
\hline & 女おかぜ & 1958 & 11 \\
\hline 站 莪芴 & 群系 $1,2,3,4$ 号 & 1960 & 群馬農試 金囟試験地 \\
\hline ホップ & 長野 1,2 号 & 1958 & 長野農試 \\
\hline 楮 & 別府 1,2 号 & 1958 & 高知叟試 \\
\hline
\end{tabular}

